\title{
RUMOR, BELIEF, AND CONTESTATION AMID THE CONVERSION MOVEMENT TO ORTHODOXY IN NORTHERN LIVONIA, 1845-1848
}

\section{Daniel C. Ryan}

\begin{abstract}
This essay seeks to explore peasant strategies of contestation amid the episode of mass conversion to Orthodoxy in the Baltic province of Livonia, 1845-1848, which occurred amid a cycle of rumors promising worldly benefits for taking "the Tsar's faith." Converts and prospective converts frequently attributed obstructionist and persecutory actions to local authorities, and many peasants broke local ordinances or defied recent decrees in seeking to convert. The ubiquity of complaints, refusals, and infractions suggests that conversion offered a means of social protest and also raises questions regarding putative belief in the rumors.
\end{abstract}

Keywords: conversion, Eastern Orthodox Church, Estonia, Livland/ Livonia, peasants, rumor, Russia-Imperial

The astonishing mass conversion of more than 100,000 Lutheran Estonian and Latvian peasants to the Russian Orthodox faith during 1845-1848 remains a perplexing phenomenon. The now standard explanation for this astounding occurrence stems largely from two aspects of the era that have yet to be explored deeply with respect to the conversions. Namely, the conversions took place during a period of agricultural crisis and amid a series of rumors that suggested conversion to "the Tsar's faith" would yield worldly benefits: freedom from manorial authority, land to be held without obligation, tax relief, and so on. Given the seeming preoccupation with material gains apparent in the rumors and the economic situation of the era, contemporary commentators and later historians have tended to view the conversions as the act of desperate and credulous peasants who were misled by rumors (Kruus 1930). ${ }^{1}$ While the agricultural situation and rumors are not to be ignored, I suggest that excessive attention to these factors has led scholars to emphasize credulity and desperation at the expense of discussions 
of peasant behavior amid a period of social contest. Evidence of peasant claims and acts of disobedience - in particular illegal departures from manors and false complaints about religious persecution - need to be integrated into the study of the conversion phenomenon. While this essay focuses primarily on the northern half of Livonia (situated in the southern portion of present-day Estonia) the rumors, complaints, and acts of insubordination under discussion certainly occurred in the Latvian-speaking countryside of the province as well.

Rumors and the ensuing mass conversion of rural Livonians created a fluid situation that allowed peasants to contest their social status and obligations. In effect, peasants appropriated an Orthodox religious status, not only through conversion, but also while attempting to convert or while enduring the mandatory waiting period between "signing up" to convert and formally converting. In order to depart from the stereotype of naive, desperate peasants it is useful to consider a single rumormonger, whose belief in the rumors he told is highly questionable.

The case of Juhan Levenson is interesting because his motivations for spreading rumors seem entirely more mischievous than credulous: he wore a cross that he fashioned out of copper buttons which he wore while masquerading as a recent convert. While visiting Tori manor in Pärnu district, some seventy-five kilometers from his village, he was arrested and investigated for spreading false rumors in December 1845. Levenson told a number of peasants that converts would receive three rubles, three bushels of grain, and warned that conversions would cease in three weeks. Having initially hidden the cross while claiming to be Lutheran, upon its discovery, he later claimed to have converted to Orthodoxy ten weeks prior to his arrest. Puzzled by the inconsistencies of Levenson's testimony, the magistrate pressed on with more questions about the cross. Levenson suggested that he hid the cross, believing that it was forbidden to wear any cross but that given upon conversion. He claimed to have lost that one on the way back from the church in Mustvee where he had supposedly converted, adding that his reticence to reveal his "true" religious status was based on his fear that this "fact" might implicate him further in spreading rumors. The chronology of his story was particularly confusing to the mag- 
istrate because it was largely fabricated and constantly shifting. Suffice it to say, he had been wandering around with a cross and claiming to have been Orthodox while speaking to others about various benefits to be received through conversion. Levenson may have intended to add weight to the claims of his rumor message by appropriating an Orthodox affiliation. ${ }^{2}$ Or perhaps the cross represented a playful, if subversive, self-fashioning during a period of rumor and peasant unrest. After all, before the magistrate he claimed he did not believe the rumors he heard in various taverns, and had only re-told them for humorous purposes. In any case, Levenson is a clear example of a peasant who did not naively or deeply believe the content of his own rumor message, if he believed it at all (EAA f. 291 , nim. 8, s. 777: 4-9).

I suggest that Levenson's case typified the Livonian experience amid the conversions of the 1840s. The rumors and religious conversions in rural Livonia created a fluid situation in which peasants made claims based upon an Orthodox religious affiliation, often before formally converting. While peasant converts (and those "signing up" to convert) seem to have been preoccupied with the benefits articulated in rumors, like Levenson, there is not much evidence that they actually expected to receive the specific benefits the rumors seemed to promise. Instead, converts and prospective converts pushed forward much narrower claims touching upon rights, status and obligation. Mostly, they brought complaints to Orthodox priests that they were being mistreated or wrongly punished by the manor or communal government as a direct result of their conversions or their declarations of intent to convert. In this way, peasants claimed to have been evicted, denied grain from the communal granary, refused work as laborers, insulted, or to have been threatened with reprisals for converting. Moreover, the vast majority of complaints were baseless. Given the dubious nature of peasant complaints, and the frequency of complaints from the unconverted, it seems that the rumors promising material gain were not believed as deeply or as literally as many historians and contemporary observers have suggested. Instead many Livonian peasants pressed much narrower claims on the basis of an Orthodox affiliation, whether or not they had yet converted. Many peasants may have even found a certain utility in straddling between the Orthodox and Lutheran confessions. This essay will examine peasant strategies of contestation 
amid the fluid situation created by the rumors and conversions, while suggesting that peasant behavior and the appeal of the rumors can be understood by examining their function and relative utility.

\section{OVERVIEW OF CHURCH AND STATE POLICIES}

The rumors and subsequent conversions, which began in late spring and early summer 1845, were of great interest to State and local officials, as well as Orthodox clergy. The evolving state policies and procedures that arose amid the rumors and conversions were informed to a great extent by the official religious policy that began to crystallize during the 1830 s, which increasingly favored Orthodoxy, already the official religion of the empire. In this way, the Orthodox Church gained prerogatives over children of mixed Orthodox and "foreign-faith" parentage, even those of officially sanctioned churches, such as the Lutheran Church (Haltzel 1981: 112, 121-122; Thaden 1984: 172). At the same time, Orthodox schismatics and sectarians came under increased surveillance, and evergreater pressure to convert to Orthodoxy (Gavrilin 1999: 40-46). ${ }^{3}$ While the religious policies of Nicholas I explicitly promoted the spread of the Orthodox Church, the policies unfolding in Livonia during the 1840s also owed a great deal to the course of events amid the rumors and conversions.

The major conversion policies instituted between 1845-1848 took shape as a result of the concerns of manorial officials, landlords, and rural authorities on the one hand, and the complaints of peasants and Orthodox clergy about hostile Lutherans on the other. From the onset of the conversions in late spring and early summer 1845 , the rural elite voiced concerns about the potential unrest that could arise from rumors, unauthorized peasant departures from the manor, and the disruption of the work routine (Naaber \& Traat 1991: 84-85). ${ }^{4}$ By contrast, the Orthodox Bishop and priests expressed alarm and indignation about the numerous reports that estate managers and landlords were forbidding peasants to convert by withholding travel documents, or persecuting those who converted (EAA f. 291 , nim. 8, s. 707: 1-6). As a result of these conflicting concerns, the Governor General issued a series of instructions and public proclamations that established the basic government policies regarding 
the conversions between July and August 1845. Orders issued July 21 instituted a waiting period until September 1 for traveling to Churches to convert or registering to convert, while a proclamation denounced the rumors as untrue, thereby addressing rural authorities' anxieties about maintaining order and work discipline. At the same time, the government also responded to the concerns of the Church by explicitly sanctioning the conversions; declaring that there was to be no interference; and forcefully stating that converts would be placed under the direct protection of the state (Naaber \& Traat 1991: 17-21). And so they were, as we shall see later. Instructions issued in late August 1845 established additional regulations for converting by limiting the number of departing peasants to one out of ten per manor; warning that those failing to obtain travel documents would not be allowed to sign-up or convert; stipulating that peasants could only travel to the nearest church; and warning that rumormongers would be punished severely (Naaber \& Traat 1991: 32-35). None of these measures brought to an end the rumors and conversions, nor did the order of January 4,1846 that established a six-month waiting period (Naaber \& Traat 1991: 44-45). In fact, the vast majority of conversions took place after the six-month waiting period was established. In northern Livonia, according to a report from Bishop Filaret, 9,900 conversions took place in $1845 ; 22,600$ in 1846; and 26,700 in 1847 (EAA f. 291 , nim. 8 , s. $1054: 25-26) .^{5}$ The quickening pace of the conversions in the wake of these proclamations and procedures begs the question, why would even the most credulous peasant remain so thoroughly deluded with respect to the rumors for so long?

\section{FALSE COMPLAINTS AND ORTHODOX STATUS}

Here I would like to return to the theme of the essay: the utility of appropriating an Orthodox status in order to make claims about rights and obligations. The supposed rush to convert seems to have been a more deliberate process for many peasants. In fact, before either of the waiting periods, procedures were already established to ensure that conversions would not be attached to false hopes about secular matters. Peasants had to formally declare their wish to convert, undergo an "examination" by way of a series of questions designed to test their "sincerity," (Naaber \& Traat 1991: 85) 
and only then could they receive Orthodox rites and the cross that symbolized their conversion. Also, even before the six-month waiting period was established, peasants usually had to wait a few weeks between their examination and their final conversion. The decree of January 1846 simply prolonged the period between these steps. Moreover, peasants could not convert or sign up to convert unless they followed the rules established in the summer of 1845 (i.e., receive permission from the manor and travel to the nearest church). Within this framework, there was a great deal of maneuvering on the part of peasants. It was all too common that peasants showed up before priests without documents from the manor, claiming that they had already been punished for requesting them, or that they were threatened with punishments if they signed up to convert. This phenomenon suggests that peasants were contesting local authority by pressing forward complaints to priests, and that perhaps many were not committing very deeply to conversion. In fact, such actions demonstrate how peasants could appropriate an Orthodox status without even converting, while nonetheless legitimizing unlawful behavior such as departing from the manor without permission. In this way, complainants could proclaim their sincere wish to convert, bemoan manorial interference, and make claims against those supposedly hostile toward Orthodoxy. Yet, by appearing without documents, peasants could neither sign-up nor convert. Given the baseless nature of most complaints, it could be suggested that peasants who appeared without permission claiming to have been obstructed, may not have been as committed to the idea of conversion as to the exploration of novel forms of social contest.

Peasant complaints were directed by Orthodox priests to Bishop Filaret in Riga, who then passed them on to the Baltic GovernorGeneral, who in turn initiated an investigation through the civil Governor. Sometimes the usual chain of authority was circumvented, and trusted high officials were dispatched in order to ensure that an investigation would be conducted thoroughly and fairly - a fact that suggests that local authorities were not entirely trustworthy in the eyes of the central government. ${ }^{6}$

In the fall of 1845, when the conversions resumed in earnest after the one-month waiting period ceased, a number of peasants began to complain about being refused permission to leave the manor, 
unfair punishments for requesting permission, and punishments for signing up and converting. To take an example from a single source (EAA f. 291 nim. 8, s. 734), the Governor-General received at least 14 complaints, arising from some 54 peasants, which the archpriest and ecclesiastical superintendent of Tartu, Berezskii recorded between October 10-18. ${ }^{7}$ One set of complaints was forwarded to Kameriunker P.A. Valuev, who was assigned to investigate the situation in Tartu. Most of the complaints relate to the refusal of manor administrators, landlords, or renters to give peasants permission to travel to Tartu to sign up and to convert. A partial list of complaints is as follows:

1) a peasant from Aakre was refused documents and given fifty blows; 2) a miller and tavern keeper from Konguta manor lost his lease as a result of his conversion; 3) four peasants from the manor Rasina were refused documents; 4) a peasant woman from Saadjärve was twice refused documents and given fifteen blows for making a second request; 5) a woman appeared along with her brother to complain that her husband was wrongly arrested for requesting travel documents, adding that he "sincerely" wished to convert; 6) eighteen peasants (only three were mentioned by name) from the manor of Karl Bruiningk were denied permission to leave; 7) seven peasants (only three were mentioned by name) from Ahja manor were refused documents; 8) the cemetery watchman of Kavilda lost his position following his request for documents; 9) twenty peasants (four of whom were mentioned by name) from Arula manor were refused documents; 10) a peasant from Kavastu manor, who had already signed up to convert, claimed to have been unfairly punished by a peasant justice for requesting permission to travel, and added that the justice called the Orthodox faith a iazycheskaia vera, or 'pagan religion' (EAA f. 291, nim. 8, s. 734: 29-32, 56-61).

By the time Valuev began to investigate the cases in late October, seven had already come under investigation by the District Magistrate, and Valuev examined the notes of the investigations. Of the seven cases, Valuev reported, only one had "some basis." While it was true that the peasant in question had been unfairly beaten with an excessive number of blows - fifty - he had not been beaten for requesting travel documents, as he claimed, for the magistrate's investigation revealed that some two-hundred had already been is- 
sued by the manor. Rather, the peasant had left without permission after being told that no more documents would be given on the day in question (presumably because the one-tenth quota limiting departures had already been exceeded). Two other cases had not yet been heard, because the complainants failed to appear when summoned by the magistrate - a fact that may suggest the lack of substance behind the claims (EAA f. 291, nim. 8, s. 734: 56-61).

Among the others supposedly punished for requesting permission to travel were a number of peasants who had never actually requested permission or had left anyway when told that the quota for departures had already been exceeded. In either case, the complaints tended to be attributed more to peasant ignorance than willful disobedience - an odd fact, considering that peasants had always needed permission to leave their manors. The decree of $\mathrm{Au}-$ gust 1845 had merely made the formal process of conversion contingent upon obedience to civil law; the passport requirement was not at all new. Peasants made numerous similar complaints to clergy in those parts of Livonia caught up in the rumors and conversion episodes during the autumn and winter of 1845 . In northern Livonia, these were primarily the districts of Võru and Tartu.

After the institution of the six-month waiting period, complaints about interference did not dissipate, but accompanied the spread of rumors and conversions to northwestern Livonia: Pärnu, Viljandi, and Saaremaa districts. For the first half of 1846, there was little new to the complaints peasants brought forward in terms of content or the lack of basis in fact. A brief summary of complaints brought to the archpriest and ecclesiastical superintendent of Pärnu follows:

1) forty peasants from a single manor were denied permission to travel (EAA f. 291, nim. 8, s. 872); 2) a peasant from Tõstamaa manor in Pärnu received corporal punishment for requesting permission (EAA f. 291, nim. 8, s. 849); 3) another peasant was punished on three occasions for repeatedly requesting permission to travel to convert (EAA f. 291, nim. 8, s. 849); 4) a peasant from a manor in Valga district claimed to have been cruelly punished for leaving the manor, even though he conscientiously found a replacement to perform his labor obligation during his absence (did he fail to acquire travel documents?) (EAA f. 291, nim. 8, s. 1014); 5) others were 
jailed (EAA f. 291, nim. 8, s. 934); 6) another received seventy lashes (EAA f. 291, nim. 8, s. 976); 7) a pregnant woman was even subjected to corporal punishment, in contravention of law (EAA f. 291, nim. 8, s. 976); 8) one peasant came in tears, complaining to have been beaten for repeatedly asking permission to depart (EAA f. 291, nim. 8, s. 973); 9) another peasant was not only denied permission to leave the manor, but also threatened with eviction if he converted (EAA f. 291, nim. 8, s. 797). Such was the lot of prospective converts, or so they claimed.

Priests took down numerous complaints about such purportedly blatant acts of persecution between 1845-1850. Some reports are quite vague, providing no information - even names - about the particular peasants who brought their situation to the attention of Orthodox priests. Other reports provide brief descriptions of the basic issues at hand, all ostensibly from the point of view of the complainant.

It has already been established that many complaints were baseless. For now, it is useful to consider the variety of complaints and what they convey. The "message" of these complaints, as I understand it, is that peasants proclaimed a sincere desire to convert, but were thwarted by cruel and unjust landlords and estate managers. The evident appeal to pathos becomes even clearer in other kinds of complaints, particularly those relating to "unfair" evictions or the refusal of landlords to give grain to converts during times of dearth, ${ }^{8}$ which peasants claimed were reprisals for converting to Orthodoxy.

One of the earliest examples I have found of this type of complaint was taken down by Berezskii in October, 1845, when a recent convert from Raadi manor claimed the landlord tore his cross off, told him "I don't need Russians here!" and arbitrarily evicted him (EAA f. 291, nim. 8, s. 734). In December, Berezskii reported that several peasants had come before him, declaring among numerous other things, that they had been evicted for converting. When an investigation began in January, Berezskii indicated that five peasants from Palupera manor had been ordered by the estate manager to vacate their farmsteads "because they had converted to Orthodoxy," while four peasants from Jõgeva claimed to have been driven off the manor for the same reason. Another from Vastse-Kuuste manor stated he 
had been threatened with eviction if he converted (EAA f. 291, nim. 8, s. 797).

Other complaints added additional details that made persecutory evictions seem all the worse. For example, a peasant from Tõstamaa claimed to have been punished twice, evicted, and even denied a passport, which prevented him from moving somewhere where he could make a living (EAA f. 291, nim. 8, s. 1061). Another peasant, from Vastseliina manor in Võru, added that his eviction would lead to the displacement of seventeen people (EAA f. 291, nim. 8, s. 869). Still others spoke about the great lengths of time their families had held farmsteads or allotments: fifty years (EAA f. 291, nim. 8, s. 1186); seventeen years (EAA f. 291, nim. 8, s. 1189), fourteen years (EAA f. 291,nim. 8, s. 1147), and so on, while adding that they were solvent, and that their property had even been needlessly auctioned.

The evidence provided above has mostly been presented uncritically: I give little sense of the basis for, and outcome of, the numerous complaints about persecution and obstruction. While priests remained convinced of the hostility of Lutherans - particularly landlords - there is good reason to be skeptical about the allegations of religious persecution in Livonia. Two of the most patently ridiculous cases are discussed below.

In May 1846, a convert from Mõniste manor told the priest that he was denied grain from the communal reserve. He claimed to only receive a small amount for the sole unconverted member of his family - a small child. The situation was supposedly so dire that two members of his family had already died. Yet the investigation revealed that he had received nine separate loans of grain, that all of his children were adults, including a shirker-of-an-eighteen-yearold son, the only offspring still living at home. The magistrate's investigation further revealed that one-quarter of the population of the manor had converted, and that Orthodox were not, in fact, starving. The peasant offered no additional explanation, and was punished for making a false complaint (EAA f. 291, nim. 8, 879).

Jüri Madison issued a similarly ridiculous complaint. The peasant, from Laiksaare manor in Pärnu claimed that he had been punished with sixty blows; that he was held under arrest for six weeks; that none of his fellow peasants would take him in as a hand; that he 
was unable to borrow grain; and that the manor administrator would not issue him a passport to work outside the estate. As a result of all this, he alleged that he was unable to find work of any kind, and thus could not pay his obligations, which only led to additional punishments. The parish magistrate found that these contentions were all fabricated. Madison admitted that he had not been punished or jailed for converting, but for telling false rumors. It was true that the local peasant administration would not give him any grain, but they contended that he had significant debts and, as a "strong, healthy, and able" man, held that he should work. Before the magistrate he denied ever claiming that no one would hire him because he was Orthodox, and attributed his unemployment to overpopulation on the manor. However, local peasant officials suggested that his poor reputation kept him from finding work. Finally, Madison denied having complained that the manor withheld his passport (EAA f. 291, nim. 8, s. 1111).

Cases such as the two above were very difficult to prove, most often because estate managers could provide records of arrears and cite Orthodox converts who were solvent and left to their own devices. While peasants seldom received satisfaction from their complaints, complaints persisted throughout the conversion era, and to a lesser extent into the 1850 s and 1860 s. While the immediate outcome of most investigations was not favorable to complainants (and many dropped their complaints as soon as investigations began), their significance might nonetheless have been to encourage conversions further. Indeed, some complaints led to investigations that dragged on for years, and the very fact that complaints received attention may have led many peasants to decide that conversion was not a bad idea. It could be suggested that the willingness of priests to accept complaints, and the measures the central government took to protect (prospective) converts may have encouraged a great number of peasants to convert at the end of their six-month wait. ${ }^{9}$ In its turn, the phenomenon of complaints also helps to shed light on the phenomenon of belief in the rumors. 


\section{RUMOR AND BELIEF, BELIEF AND ACTION}

Given the dubious nature of peasant complaints, and the example Levenson provides of a mischievous rumormonger, what are we to conclude about belief with respect to the rumors of the 1840s? What kind of belief - if we can even speak of such a thing - operated in the countryside during the conversion era? The discussion presented above should help us to avoid an overly simplistic view of converts' motivations, yet the question of belief in the rumors needs to be addressed further.

It is useful first to define rumor; two oft-cited definitions are provided and critiqued in order to explore the nature of rumor in Livonia more deeply. First, a rather straightforward definition of rumor is simply unverified information, transmitted at a rapid frequency (Yang 1987: 485; Fine \& Rosnow 1976: 4). Second, Shibutami defines rumor as "a recurrent form of communication through which men caught together in an ambiguous situation attempt to construct a meaningful interpretation of it by pooling their intellectual resources" (1966: 17). Kapferer provides useful perspectives on the limitations of both of these definitions. He points out the notion of an official source (i.e., that might verify or refute rumor) is a political notion, "governed by a consensus about who has the jurisdiction to speak" (1990: 14). Thus, to paraphrase Kapferer, rumor implies a relationship to authority (1990: 7, 14); it functions as an uncontrolled source of information. Rumor is not merely idle speculation, but rather a phenomenon of great concern for authorities. As for the second definition, it can be suggested that Shibutani focuses too narrowly on the role of events in creating rumor. Kapferer reminds us that rumors also create events (1990: 9). What, if anything, was the "ambiguous situation" that sparked the rumors? The agricultural crisis? The conversion of a small number of Latvians in Riga during the spring of 1845 ? While either or both of these "events" may have played a role in the formation of rumors, the origins are far less important than the result: intimations of unrest, acts of disobedience, and the conversion of more than 100,000 Livonians. I do not mean to suggest that either of the two definitions of rumor above should be discarded, but that they fail to account more fully for the situation in Livonia. ${ }^{10}$ 
For the purposes of this essay, it is important to keep in mind that rumors may occur for indeterminate reasons, that they create situations as much as they originate from them, and that they must be understood in relation to authority and power. The persistence of rumors in Livonia cannot be attributed simply to a putative deep belief in them. Proclamations and procedures, such as the testaments of sincerity signed by converts, repeatedly reminded peasants that the rumors were false. This information did reach the countryside, and with time it became more and more difficult for peasants to openly profess belief in the rumors. Authority did not likely leave "belief" untouched yet conversions persisted for more than three years.

How can the evident disruptive behavior of peasants be reconciled to belief in rumors?

A preliminary answer can be offered by borrowing perspectives from the work of David Sabean. Sabean posits an on-going process of negotiation between authorities and their subjects. Since bureaucratic institutions and coercive power tend to favor the former, he suggests that, "the chief weapon on the part of the dominated sometimes lies in the simple act of gawking, the rush to join the crowd, the excitement of new belief"(1984: 26-27). If we set aside a notion of "belief" that is overly focused on deep internal conviction, it is entirely possible to suggest that peasants did believe the rumors, if not always literally. The rumors offered a counterpoint to the official line (Kapferer 1990), in essence, a new belief that could be tested (Sabean 1984).

In so doing, peasants could also excuse otherwise impermissible acts, especially amid an emerging belief that had not yet been contested or effectively refuted by authorities. For example, by autumn of 1845 , it was already far less possible for peasants to profess belief in rumors openly. Those arrested for spreading rumors usually denied having done so, while explicitly disavowing belief. Yet, at other junctures, peasants could avoid professing belief, but still act according to the ebullient message of the rumors, especially when "misunderstanding" decrees. Kruus notes that there were cases of peasants appearing before priests professing to believe that they were supposed to convert following the decree of August 21 (1930: 200). Likewise, in the autumn of 1845 , peasants from Võru and 
Tartu districts frequently left their manors to sign-up and convert without permission, claiming to have been unaware of the specific policies regulating departure from the manor. Given the rumors and stereotypes about peasant backwardness, authorities tended to excuse such behavior, and viewed the "misunderstandings" as stemming from ignorance and insufficiently publicized proclamations. After additional efforts to communicate and enforce the policy regarding travel documents, by late October, the problem had abated (EAA f. 291, nim. 8, s. 723: 6-7, 10-11; s. 734: 7, 22-23, 39-43; s. $721,8-9)$.

A similar phenomenon occurred in Pärnu district in late spring, 1846, when perhaps two hundred peasants from manors in the vicinity of the district town came before the Orthodox priest to learn more about the faith (EAA, f. 291, nim. 8, s. 858: 37-38, 40-41, 47$48,50-56,62-63,73-84)$. These peasants, who were mostly abiding the six-month waiting period, claimed that their landlords ordered all those who had signed up to convert to study their "new faith" in Pärnu for periods of a week or more. While a recent proclamation in the region had given peasants authorization to study with priests, there was certainly no compulsion to do so. Peasants in this case spoke of punishments (fines and corporal punishment) for anyone failing to fulfill the "order." While authorities - especially clergy considered the possibility that peasants had indeed been threatened, far less attention was paid initially to the illegal departures and willful misinterpretation of the proclamation. The Church found the notion of compulsory religious study particularly odious, and maintained that this should only be done out of conviction and free will.

In this case, rumor and complaint were fused together. Civil authorities sought to get to the bottom of the matter, at first focusing on the alleged arbitrary threats of the estate managers in question. Then, when it became clear that peasants had "misunderstood" the proclamation, they sought to uncover the source(s) of the "distorted" message (EAA f. 291, nim. 8, s.858; s. 905). Belief was indeed useful for peasants and authorities. On the one hand, authorities had only to find a few cynical manipulators who misled the usually-obedient majority of peasants. On the other, peasants could profess belief (or miscomprehension) and attribute their actions to erroneous information. ${ }^{11}$ The apparent utility of belief in the rumors, and the gov- 
ernments' responses to complaints likely served to reinforce and propel the rumors further. Under emerging circumstances, such as new decrees, peasants could justify disobedience in novel ways.

This essay has attempted to shed light onto the nature of belief in the rumors while examining the actions of peasants in Livonia amid the tumultuous events of 1845-1848. In so doing, I have straddled awkwardly between the poles of belief and disbelief, only to vaguely suggest that some kind of belief in the rumors was at play. In urging caution that we not attribute a deep or static form of belief, I hope to suggest that Livonian peasants' motivations were not as straightforward as they might appear. While the exact aims of peasants are elusive (above all because they were not as homogenous as most commentators would have them be), it is at least important to keep in mind that they were hardly as helpless or pliant as they are often depicted to have been. While the outcome of the conversions has yet to be adequately studied, suffice it to say that the stereotype of the unhappy convert ${ }^{12}$ that pervades most accounts may elide the more complex set of motivations and actions underway in the decades after the conversions.

\section{Comments}

${ }^{1}$ Kruus is the most frequently cited authority on the conversions, and his work has been the most influential to date. Thaden assumes essentially the same motivations on the part of peasants, noting that conversions ceased when it was clear that no benefits were to be had (1984: 179-180). The most recent study of the conversions and the history of the Orthodox Church in the Baltic is by Gavrilin (1999), who fails to reassess the materialist assumptions at work in earlier explanations of peasant behavior.

${ }^{2}$ The Mustvee priest had no record of any person by the name of Juhan Levenson having converted. See Estonian Historical Archives (Eesti Ajaloo Arhiiv) fond 291, nimistu 8, säilik 777: 43. Hereafter, EAA f., nim., s.

${ }^{3}$ Laws promulgated in the 1830 s forbid the registration of schismatic merchants as urban residents as well as their entry into urban guilds, while prohibiting the renovation of places of worship. Schismatics were pressured to marry within the Orthodox Church through laws that declared children to be illegitimate without canonical marriages within an official faith. These measures are all cited in Gavrilin. 
${ }^{4}$ For example, the Governor General received reports about illegal departures of peasants from two manors in Võru district in late June 1845. The magistrate's report cites both the potential for unrest and the disruption of agricultural labor as both potentially dangerous - the latter especially so during an already dry summer.

${ }^{5}$ Regarding Latvian converts, the same source shows 4,600 converts for $1845 ; 10,200$ for 1846; and 21,000 for 1847. Church records show that 65,683 Estonians had converted by April 1848; see, EAA f. 291, nim. 8, s. 1278: 3-4.

${ }^{6}$ In at least one case, Bishop Filaret explicitly requested a non-German official investigate claims of mistreatment. See EAA f. 291, nim. 8, s. 1021.

${ }^{7}$ There may be reason to be skeptical about the accuracy of these numbers, especially in cases said to involve larger groups of peasants issuing the same complaint: the documents usually mention a few peasants by name, adding to the list, "and others." Nonetheless, it is significant that the complaints received attention and were taken seriously.

${ }^{8}$ For example, in early 1846 the Võru priest reported that four peasants from two different manors proclaimed that they were "dying of hunger," and lacked "even a piece of bread," because their landlords refused to give them grain. One landlord purportedly said, "you are Russian now, go ask for bread from the Russians" (EAA, f. 291, 8, nim. 796).

${ }^{9}$ Kruus makes the point that priests' willingness to hear complaints added to peasant "misconceptions" and reinforced expectations (1930: 224-225).

${ }^{10}$ One noticeable lacuna in the scholarship of rumor is the phenomenon of ebullient rumors, such as those of Livonia during the $1840 \mathrm{~s}$. The central focus of most studies of rumor in general has so far been limited to socalled "black" rumors, touching upon possibly threatening events (Kapferer 1990: 130-135).

${ }^{11}$ Field (1976) suggests that Russian peasants took advantage of stereotypes about their ignorance in seizing on monarchistic rumors during periods of unrest.

${ }^{12}$ Kruus and others suggest that dissatisfaction arose when hopes of benefits dissipated, which is to say that peasants were essentially tricked into converting. By contrast, Orthodox priests remained convinced that dissatisfaction arose from constant persecution and economic misery. See EAA f. 1655 , nim. 2, s. 1432. 


\section{References}

Field, Daniel 1976. Rebels in the Name of the Tsar. Boston: HoughtonMiflin.

Fine, Gary Alan and Rosnow, Ralph 1976. Rumor and Gossip. The Social Psychology of Hearsay. New York: Elsevier.

Gavrilin, A.V. 1999. Ocherki istorii Rizhskoi eparkhii 19 vek. Riga: Filokaliia.

Haltzel, Michael 1981. The Baltic Germans. Edward Thaden (Ed.) Russification in the Baltic Provinces and Finland, 1855-1914. Princeton: Princeton University Press.

Kapferer, Jean-Nöel 1990. Rumors. Uses Interpretations and Images. New Brunswick and London: Transaction Publishers.

Kruus, Hans 1930. Talurahvakäärimine Lõuna-Eestis, XIX sajandi 40ndail aastail. Tartu.

Naaber, V. \& Traat, A. (Eds.) 1991. Talurahvaliikumine Eestis Aastail 1845-1848. Dokumentide Kogumik. (2 vols.) Tallinn: Eesti Vabariigi Arhiiviamet.

Sabean, David 1984. Power in the Blood. Popular Culture and Village Discourse in Early Modern Germany. Cambridge: Cambridge University Press.

Shibutani, Tamotsu 1966. Improvised News: A Sociology of Rumor. Indianapolis and New York: The Bobbs-Merrill Company, Inc.

Thaden, Edward C. 1984. Russia's Western Borderlands, 1710-1870. Princeton: Princeton University Press.

Yang, Anand 1987. A Conversation of Rumors: The Language of Popular Mentalitès in Late Nineteenth-Century Colonial India. Journal of Social History, 21 (Spring 1987), pp. 485-505. 